\title{
Predictions of Social Support on School Counselors' Performances
}

\author{
Suharso $^{1}$, Sugiyo $^{2}$, Rusdarti $^{3}$ \\ \{ $\underline{\text { suharso@mail.unnes.ac.id }}{ }^{1}$, sugiyo@ mail.unnes.ac.id ${ }^{2}$, rusdarti@mail.unnes.ac.id $\left.{ }^{3}\right\}$
}

Universitas Negeri Semarang, Semarang Indonesia ${ }^{1,2,3}$

\begin{abstract}
Social support is an important contributive factor to improve counselors' performances. This research aims to analyze social support prediction to counselors' performances at schools. The population consisted of all junior high school counsellors in Semarang residency. The sample consisted of 155 counsellors from Semarang, Semarang regency, and Demak taken by cluster proportional random sampling. Techniques of collecting data used performance and social supports of school counsellor performance with 5 answers. Instrument validity showed that 40 items were valid with coefficient between $0.221-0.738$. Reliability test gained coefficient 0.926 , meaning that the test was reliable. The data analysis used linier regression. The findings showed that social supports had various predictions to improvement of each counselors' performance aspects. Specifically, planning actual performance was predicted positively by information and instrumental support. Meanwhile, actual implementation, actual assessment, and actual follow up performance were predicted positively by information supports and acknowledgement. Implication of practical social supports at school is discussed in this article.
\end{abstract}

Keywords: school counselors' performance, social support

\section{Introduction}

Heretofore, counselors' performances at school in Indonesia have not been optimal. The government has put some efforts to improve their performance such as by teacher certification started from Portfolio, Teacher and Training Education (PLPG) ${ }^{[1]}$, and now currently named Teacher Profession Education for both in-position ${ }^{[2]}$ and pre-position ${ }^{[3]}$. Those certified counselors at school would further gain professional incentives. Thus, it is expected for them to be more competent, professional, and finally to have optimal performances.

The on-going phenomena does not seem proportional. Those certified educators do not show better competences and performance. Several studies showed they still had unprofessional performances. Yari (2016) found counselors' performances in Salatiga were categorized moderate or insufficient. Furthermore, it was found significant differences between certified counselors' performances to those uncertified counselors' performances[4]. Siregar (2018) revealed that guidance and counseling teachers' performance on field were not optimal. It was caused due to lack of knowledge and skill of the counsellors in approaching the students[5]. Interview result with GCTD Chief of Semarang city (2018) showed the performances of JHS counselors were not optimal for both planning, executing, evaluating, and following up programs[6]. 
By considering those phenomenon, it showed that current efforts still have not had any expected result. When it is observed carefully, the efforts of improving the performances still focus on improving competences, such as pedagogical and professional competences. In fact, performance is not always determined by competence but instead many factors both internal and external. One of the most influential factors which gains few attention is social support from both leader and peers. Yuan et al (2017) found social support significantly influenced actual performance[7]. The ASCA National Model (2005) stated that school counselors' main responsibility is to develop programs to respond academic, social/emotional and career needs of students. It is virtually impossible for school counselors to create a truly comprehensive counseling program that addresses these different components without fostering collaborative relationships[8].

This research is intended to analyze social support as predictor of JHS counselors' performance in Semarang residency. The findings would be useful for school counselors, principals, and stakeholders in developing school counselors' performance in JHS.

\section{Method}

This quantitative research is an explanatory and expos-facto.

The population consisted of all JHS counselors in Semarang residency taken by cluster proportional random sampling. Based on the sampling technique, it was gained three regencies: Semarang city, Semarang regency, and Demak with 277 participants as the population. Based on Isack \& Michael Table, with error level 5\%, it was gained 155 participants as sample.

Techniques of collecting data used counselor performance and social support of school counselor questionnaires. Those questionnaires were closed question questionnaires with 5 answers. The counselor performance questionnaire consisted of 20 items to reveal 4 indicators: (1) planning, (2) implementing, (3) assessing, and (4) following up. The social support of school counselor consisted of 20 items to reveal 4 indicators: (1) emotion, (2) information, (3) reward, and (4) instruments. Validity test showed that all items were valid with coefficient 0.221 to 0.738 . Meanwhile, reliability test showed it was reliable with coefficient 0.926 . Technique of data analysis used multiple linier regression with stepwais using IBM SPSS Statistic 22.

\section{Results and Discussion}

Descriptively, the data analysis showed that both social support and counselors' performance were high. Meanwhile, when it was seen from its inter-correlation, it showed all social support positively predicting counselors' performance as detailed in the table 1 . 
Table 1. Inter-correlation matrices of all variable, mean, and standard deviation

\begin{tabular}{|c|c|c|c|c|c|c|c|c|}
\hline \multirow{2}{*}{\multicolumn{9}{|c|}{$\overline{\mathrm{X} 1}$}} \\
\hline & & & & & & & & \\
\hline $\mathrm{X} 2$ & .77 & & & & & & & \\
\hline X3 & .69 & .75 & & & & & & \\
\hline X4 & .72 & .74 & .73 & & & & & \\
\hline Y1 & .44 & .48 & .47 & .48 & & & & \\
\hline Y2 & .44 & .44 & .44 & .38 & .74 & & & \\
\hline Y3 & .45 & .48 & .46 & 41 & .75 & .79 & & \\
\hline Y4 & .38 & .45 & .43 & .43 & .73 & .78 & .79 & \\
\hline M & 4.10 & 4.12 & 3.95 & 3.96 & 4.14 & 3.93 & 3.93 & 3.84 \\
\hline SD & 0.65 & 0.65 & 0.64 & 0.65 & 0.68 & 0.60 & 0.72 & 0.72 \\
\hline Range & $1-5$ & $1-5$ & $1-5$ & $1-5$ & $1-5$ & $1-5$ & $1-5$ & $1-5$ \\
\hline
\end{tabular}

Results of multiple regression analysis indicated that counselors' performances in planning, implementing, evaluating, and following up the programs were predicted by social support as shown on this table 2 .

Table 2. The results of multiple regression analysis of school counselors' performances.

\begin{tabular}{|c|c|c|c|c|c|c|c|c|c|c|c|c|}
\hline \multirow{2}{*}{ Predictors } & \multicolumn{3}{|c|}{$\mathrm{Y} 1$} & \multicolumn{3}{|c|}{$\mathrm{Y} 2$} & \multicolumn{3}{|c|}{ Y3 } & \multicolumn{3}{|c|}{$\mathrm{Y} 4$} \\
\hline & B & $\mathrm{t}$ & $P$ & $\beta$ & $t$ & $\bar{p}$ & $\beta$ & $t$ & $\bar{p}$ & $B$ & $\mathrm{t}$ & $\mathrm{P}$ \\
\hline $\mathrm{X} 1$ & .10 & 0.87 & $>.05$ & .19 & 1.67 & $>.05$ & .15 & 1.32 & $>.05$ & .01 & 0.12 & $>.05$ \\
\hline $\mathrm{X} 2$ & .27 & 2.71 & $<.01$ & .25 & 2.36 & $<.05$ & .31 & 2.96 & $<.01$ & .29 & 2.70 & $<.01$ \\
\hline X3 & .16 & 1.41 & $>.05$ & .25 & 2.35 & $<.05$ & .23 & 2.16 & $<.05$ & .21 & 1.99 & $<.05$ \\
\hline X4 & .28 & 2.71 & $<.01$ & .02 & 0.02 & $>.05$ & .02 & 0.87 & $>.05$ & .14 & 1.22 & $>.05$ \\
\hline $\mathrm{R}$ & & .51 & & & .47 & & & .51 & & & .47 & \\
\hline $\mathrm{R}^{2}$ & & .26 & & & .23 & & & .26 & & & .22 & \\
\hline$F(1,52)$ & & 26.82 & & & 22.07 & & & 26.21 & & & 21.92 & \\
\hline $\mathrm{P}$ & & $<.01$ & & & $<.01$ & & & $<.01$ & & & $<.01$ & \\
\hline
\end{tabular}

Table 2 informs that: Actual planning performance (Y1) was predicted by social support. Variances of Y1 could be explained by social support with percentage 26\%. Information support (X2) and instrumental support (X4) positively predicted $\mathrm{Y} 1(\beta=.27, \mathrm{t}=2.71, \mathrm{p}<.01$; $\beta=.28, \mathrm{t}=2.71, \mathrm{p}<.01$, respectively).

Actual implementation performance (Y2) was predicted by social support. Variances of Y2 could be explained by social support with percentage $23 \%$. Information support (X2) and reward support $(\mathrm{X} 3)$ positively predicted $\mathrm{Y} 2(\beta=.25, \mathrm{t}=2.36, \mathrm{p}<.01 ; \beta=.25, \mathrm{t}=2.35, \mathrm{p}<$ .01 , respectively).

Actual evaluation performance (Y3) was predicted by social support. Variances of Y3 could be explained by social support with percentage $26 \%$. Information support (X2) and acknowledgement support or reward (X3) positively predicted $\mathrm{Y} 3(\beta=.31, \mathrm{t}=2.96, \mathrm{p}<.01 ; \beta$ $=.23, \mathrm{t}=2.16, \mathrm{p}<.05$, respectively).

Actual follow up performance (Y4) was predicted by social support. Its variances could be explained by social support with percentage 22\%. Information support (X2) and acknowledgement support (X3) predicted Y4 $(\beta=.29, \mathrm{t}=2.70, \mathrm{p}<.01 ; \beta=.21, \mathrm{t}=1.99, \mathrm{p}<$ .05 , respectively).

Overall, school counselors' performances were predicted by social support. This finding is in line with Yuan (2017), finding out that social support significantly influenced 
performance[7]. Choi (2018) also found out social support was correlated significantly to performance[9]. Shah (2017) also stated that social support was correlated significantly to performance[10]. Peters et al (2016) found out low social support was potential to be predictor of lower performance[11]. Wang (2014) found out that peers' supports enhanced negative effects of family to job conflict on performance. Peers' supports weakened correlation between WFC to performance[12].

Among those social supports, one of them - information support - predicted all types of performance (planning, implementing, assessing, and following up). Acknowledgement support predicted three performances (actual implementation, assessment, and follow up performances). Instrumental support only predicted planning performance. Meanwhile, emotional support did not predict school counselors' performances.

Based on the information, it could be concluded that counselors' performance as school needed better social support from both leaders and peers. Especially dealing with information, acknowledgement, and instrumental supports. Information support predicted all types of performance. It indicated that social support was important information of performance. It is supported by Rajnoha (2017) finding out that Information Management System utilization was strongly and significantly correlated to performance[13]. Besides that, acknowledgement support was important for performance. Acknowledgement support predicted actual implementation, assessment, and follow up programs.

\section{Conclusion}

School counselors' performances were predicted by social support. Information social predicted all types of performances. Acknowledgement social support predicted three types of the performances (implementation, assessment, and follow up performances). Instrumental social support only predicted actual planning performance. Social emotional support did not predict performance. Therefore, to improve school counselors' performances, especially at JHSs, could be done by improving social information and acknowledgement support. Besides that, it can be done by improving social instrumental support, especially dealing with actual planning performance.

Acknowledge. In this occasion, I would like to thank the postgraduate director who had given research permission, to the promotor, co promotor, and promotorer member who has guided in this research. Also to the Chief of GCTD Semarang city, Semarang regency, and Demak regency for facilitating data collection. And for all Guidance and Counselor teacher who have participated as respondents in this study. 


\section{Reference}

[1] Peraturan Menteri Pendidikan Nasional Nomor 18 Tahun 2007 tentang Sertifikasi bagi Guru Dalam Jabatan

[2] Peraturan Menteri Pendidikan dan Kebudayaan Nomor 37 Tahun 2017 tentang Sertifikasi Bagi Guru dalam Jabatan yang Diangkat sampai dengan Akhir Tahun 2015.

[3] Peraturan Menteri Pendidikan danKebudayaan Nomor 87 Tahun 2013 tentang Program Pendidikan Profesi Guru Prajabatan.

[4] Dwikurnianingsih, Yari.: Differences in Teacher Guidance and Counseling Performance Based on Acquiring Educator Certificates and Educational Background. Satya Widya Journal. Vol. 27 (1) p45-56 (2011)

[5] Siregar, Y.: Effect of Principal Leadership Style on Guidance and Counseling Teacher Performance in East Jakarta Public High School. Teraputik: Guidance and Counseling Journal. Vol 1 (3) p232-238 (2018)

[6] Interview result about school counselor performance with GCTD Chief of Semarang city (2018)

[7] Yuan D. L., Chiu C. L, Min T. C., Chen F. H.: The Impact of Social Support on Job Performance: The Empirical Study of Mediating and Moderating Effects of Related Variables. International Journal of Organizational Innovation. Vol. 10 Issue 1, p290-317. 28p. 1 Diagram, 14 Charts, Taiwan (2017)

[8] ASCA.: The Role of The School Counselor. (2005)

[9] Bong, S. C.: Influence of Social Support and Resilience on The Nurse Job Performance. Indian Journal of Public Health Research \& Development. Vol 9(3):788-792. Republic of Korea(2018)

[10] Shah, Rakhee.: Job Stress, Social Support and Job Performance: A Study on Nurses. An International Multidisciplinary Research Journal. Vol 7 (9):72-96, Nepal (2017)

[11] Peters, E., K. Spainer., I. Mohnberg., F. M. Radoschewski., M. Bethge.: Social Support as A Resource for Work Ability. Die Rehabilitation [Rehabilitation (Stuttg)] Vol. 55 (2), pp. 102-7 (2016)

[12] Wang, M. L.: Work - Family Conflict and Job Performance in Nurses: The Moderating Effects of Social Support. The Journal Of Nursing Research: JNR. Vol. 22 (3), pp. 200-7 (2014)

[13] R, Rajnoha and Dobrovic, J.: Managerial Information Support for Strategic Business Performance Management in Industrial Enterprises in Slovakia. Polish Journal of Management Studies. Vol. 15 Issue 2, p194-204, 11p (2017) 